\title{
TAIMETTUMISALUSTASSA OLEVIEN RAVINTEIDEN VAIKUTUKSESTA KURKUN JA TOMAATIN SIRKKATAIMIEN KEHITTYMISEEN
}

\author{
Irma SuHONEN \\ Helsingin yliopiston puutarhatieteen laitos \\ Saapunut 29. 5. 1972

\begin{abstract}
EFFECTS OF NUTRIENT SOLUTIONS ON SEEDLING EMERGENCE AND GROWTH OF CUCUMBER AND TOMATO
\end{abstract}

Irma SuHONEN

Institute of Horticulture, University of Helsinki

\begin{abstract}
The effects of different nutrient solutions, the concentration of solution $(0.1-$ $0.48 \%)$, nitrogen $(0.26 \mathrm{~g} / \mathrm{l})$ and potassium $(0.77 \mathrm{~g} / \mathrm{l})$ on seedling emergence and growth of pickling cucumber and tomato on coarse sand was studied. Experiments were made in a laboratory with temperature of $20-25^{\circ} \mathrm{C}$ and additional light of $780 \mathrm{~lx}$ or 2500 $3000 \mathrm{~lx}$, or in phytotrons. The after-effects of treatments were studied in greenhouse.

The results show that a number of nutrient solutions accelerated seedling emergence, especially the Hoagland- and $\mathrm{KNO}_{3}$-solutions and those which contained potassium or $\mathrm{NO}_{3}-\mathrm{N}$. This phenomenon decreased with an increase in temperature. Compared to the treatment with distilled water, treatments with several nutrient solutions likewise accelerated seedling growth. The effect of potassium and $\mathrm{NO}_{3}-\mathrm{N}$ on growth was stimulatory, while urea and ammonium salt treatments could inhibit growth. The aftereffects of treatments with $0.1-0.3 \% \mathrm{KNO}_{3}$ and $0.24 \%$ Hoagland-solution were positive for four weeks.
\end{abstract}

Tiedetään, että jo melko alhainen suolakonsentraatio taimettumisalustassa saattaa vaikeuttaa siemenen vedensaantia ja täten haitata sen itämistä. Sitävastoin taimettumistai sirkkataimivaiheessa olevien kasvien suhtautumista alustassa oleviin ravinteisiin on niukasti tietoa. Niinpä käytännössä kiinnitetään huomio lähinnä taimettumisalustan lämpötilaan, kosteuteen ja puhtauteen alustan lannoituksen saadessa osakseen suhteellisen vähän huomiota (vrt. Hartmann ja Kester 1968). Mayer ja Poljakoff-Mayber (1963) kuitenkin toteavat, että taimettumisalustassa olevien ravinteiden vaikutuksesta kasvin taimettuminen ja sirkkataimen kehittyminen saattavat nopeutua. Siemenen esikäsittely suolaliuoksilla voi myös nopeuttaa taimettumista (Ells 1963). 
Helsingin yliopiston puutarhatieteen laitoksella on kiinnitetty huomio siihen, että eri tavoin lannoitetuilla taimettumisalustoilla vihanneskasvien sirkkataimien varhaiskehityksessä on todettavissa huomattavia eroja ja että vastoin yleistä käsitystä taimettuminen saattaa olla nopeampaa suhteellisen runsaasti lannoitetulla alustalla kuin niukasti lannoitetulla (SuHoNEN 1970). Näiden havaintojen johdosta järjestettiin v. 1969—72 kurkulla ja tomaatilla sarja kokeita, joissa selvitettiin hiekka-alustalla 1) erilaisten ravinneliuosten, 2) liuoksen konsentration ja 3) typen sekä kaliumin vaikutusta koekasvien taimettumisnopeuteen ja sirkkataimien kehittymiseen, sekä 4) taimettumisalustaan annetun ravinneliuoksen merkitystä näiden kasvien myöhemmässä kasvussa.

\section{Menetelmät}

Koekasveina olivat avomaan kurkku (Superb) ja tomaatti (Potentat, Revermun). • Nämä kylvettiin seulotulla hiekalla (ø $0.5-1 \mathrm{~mm})$ täytettyyn taimettumisastiaan. Hiekka kasteltiin vedellä, $0.12-0.48 \%$ :lla täysravinneliuoksella (mukaeltu Hoagland-liuos, WENT 1957) taikka seuraavien suolojen liuoksilla, joiden väkevyys eri kokeissa oli 0.05 $0.3 \%$ : urea, ammonium-, kalium- ja kalsiumnitraatti, monoammonium-, monokaliumja dikaliumfosfaatti sekä kaliumsulfaatti, -karbonaatti, -kloridi ja -hydroksidi.

Kylvön jälkeen taimettumisastiat vietiin laboratorioon, missä lämpötila oli $20-25^{\circ} \mathrm{C}$ ja missä astiat haihdunnan rajoittamiseksi peitettiin värittömällä muovilla. Taimettumisen alkaessa muovi poistettiin ja ryhdyttiin antamaan lisävaloa 24 t/vrk taimien venymisen estämiseksi. Tarvittaessa suoritettiin kastelu tislatulla vedellä. Kaksi taimettumiskokeista suoritettiin kasvatuskaapeissa kontrolloiduissa lämpöoloissa. Sirkkataimivaiheessa olevat kasvit analysoitiin 5-9 vrk:n kuluttua kylvöstä. Näistä määritettiin tuorepaino, sirkkalehtien pinta-ala optisella planimetrillä tai sirkkalehtien paino, sirkkavarren pituus sekä kuivapaino $\left(105^{\circ} \mathrm{C}, 24 \mathrm{t}\right)$.

Taimettumiskokeisiin liittyvät idätyskokeet suoritettiin petrinmaljoissa, joissa olevat suodatinpaperit kasteltiin tutkittavalla liuoksella.

Taimettumisalustan käsittelyn jälkivaikutuksen selvittämiseksi koekasvit taimetettiin edellä esitetyllä tavalla ja koulittiin turvelevyihin (Finnhumus). Ennen taimien irroitusta taimettumisalustalta suoritettiin tulvitus tislatulla vedellä ja koulittaessa juurissa oleva hiekka karisteltiin mahdollisimman tarkoin pois. Jatkokasvatus tapahtui kasvihuoneessa. Jatkokasvatusajan (7-30 vrk) päätyttyä määritettiin taimien tuorepaino, lehtipinta-ala, kasvulehtien luku sekä kuivapaino $\left(105^{\circ}, 24 \mathrm{t}\right)$.

Kokeet suoritettiin lohkottain satunnaistettujen ruutujen menetelmällä ja tilastolliset analyysit Cochranin ja Coxin (1962) esittämien periaatteiden mukaan.

\section{Tulokset}

Kokeet erilaisilla ravinneliuoksilla. Alustavassa kokeessa koekasvina oli kurkku, jonka taimettumisalusta kasteltiin tislatulla vedellä taikka seuraavilla liuoksilla: $0.2 \%$ $\mathrm{NH}_{4} \mathrm{H}_{2} \mathrm{PO}_{4}, 0.2 \% \mathrm{Ca}\left(\mathrm{NO}_{3}\right)_{2}, 0.2 \% \mathrm{KNO}_{3}, 0.24 \%$ Hoagland-liuos. Neljän vuorokauden kuluttua kylvöstä todettiin, että käsittelyistä aiheutui eroavuuksia taimettumisnopeudessa. Lisäksi sirkkataimien, erityisesti sirkkalehtien, koko suureni ravinneliuosten vaikutuksesta seuraavasti: 


\begin{tabular}{|c|c|c|}
\hline Käsittely & $\begin{array}{l}\text { Sirkkalehtien } \\
\text { pinta-ala } 7 \text { vrk }\end{array}$ & $\begin{array}{c}\text { Taimettuneet } \\
4 \mathrm{vrk}\end{array}$ \\
\hline Treatment & Cotyledons 7 days & $\begin{array}{c}\text { Seedling emergence } \\
4 \text { days }\end{array}$ \\
\hline $\mathrm{H}_{2} \mathrm{O}$ & $2.3 \mathrm{~cm}^{2}$ & $12 \%$ \\
\hline $\mathrm{NH}_{4} \mathrm{H}_{2} \mathrm{PO}_{4}$ & 3.5, & 30, \\
\hline $\mathrm{Ca}\left(\mathrm{NO}_{3}\right)_{2}$ & 3.6, & 45, \\
\hline $\mathrm{KNO}_{3}$ & 6.2 , & 62, \\
\hline Hoagl. & 5.2, & 53, \\
\hline
\end{tabular}

Koe toistettiin käyttäen kurkun taimettumisalustan kastelussa edellä mainittujen lisäksi seuraavia liuoksia: $0.2 \% \quad \mathrm{~K}_{2} \mathrm{SO}_{4}, 0.1 \% \mathrm{NH}_{4} \mathrm{NO}_{3}$ ja $0.1 \%$ urea (taulukko 1). Taimettuminen alkoi 3:na vuorokautena kylvöstä lukien, ja tällöin todettiin, että vedellä kastellussa alustassa sirkkataimia oli noussut maan pintaan $41 \%$ kylvettyjen siementen määrästä. Tätä vähemmän taimettuvia oli urea-, $\mathrm{NH}_{4} \mathrm{NO}_{3}-$ ja $\mathrm{NH}_{4} \mathrm{H}_{2} \mathrm{PO}_{4}$-liuoksilla kastelluilla alustoilla ja vedellä kasteltua enemmän $\mathrm{KNO}_{3^{-}}$ja Hoagland-liuoksilla kastelluilla. Rinnakkaiskokeena suoritetussa idätyksessä ei mikään käsittelyistä merkittävästi jouduttanut kurkun itämistä. Sen sijaan Hoagland-liuos hidasti itämistä vedellä käsiteltyihin verraten.

Erilaisten ravinneliuosten vaikutus sirkkataimien kokoon oli vaihteleva (taulukko 2). Kun kylvöstä oli kulunut 5 vuorokautta, todettiin, että kaikki ravinneliuokset lisäsivät merkittävästi sirkkataimien kuivapainoa, ja 'näistä $\mathrm{KNO}_{3}$ - ja Hoagland-liuokset eniten. Urea-, $\mathrm{NH}_{4} \mathrm{NO}_{3}$ - sekä $\mathrm{NH}_{4} \mathrm{H}_{2} \mathrm{PO}_{4}$-käsittelyt ehkäisivät sirkkavarren pituuskasvua ja näiden käsittelyjen johdosta taimien tuorepaino ei merkittävästi poikennut vedellä käsitellystä. Vedellä kasteltuihin verraten suurimman muutoksen tuorepainossa, lehtipintaalassa ja sirkkavarren pituudessa aiheuttivat käsittelyt $\mathrm{KNO}_{3}-$ ja Hoagland-liuoksilla.

Taulukko 1. Ravinneliuosten vaikutus kurkun itämiseen ja taimettumiseen. Lämpötila $23-25^{\circ} \mathrm{C}$. Table 1. The effect of nutrient solutions on germination and seedling emergence of cucumber in temperature of $23-25^{\circ} \mathrm{C}$.

\begin{tabular}{|c|c|c|c|c|c|c|}
\hline \multirow[b]{2}{*}{ Käsittely } & & \multicolumn{2}{|c|}{$\begin{array}{l}\text { Itäneet \% } \\
\text { Germination \% }\end{array}$} & \multicolumn{3}{|c|}{$\begin{array}{c}\text { Taimettuneet } \% \\
\text { Seedling emergence } \%\end{array}$} \\
\hline & & 2 vrk & 3 vrk & 3 vrk*) & 5 vrk & 7 vrk \\
\hline Treatment & & 2 days & 3 days & 3 days*) & 5 days & 7 days \\
\hline $\mathrm{H}_{2} \mathrm{O}$ & & 88 & 92 & 41 & 76 & 83 \\
\hline $\mathrm{NH}_{4} \mathrm{NO}_{3}$ & $0.1 \%$ & 88 & 94 & 26 & 55 & 77 \\
\hline urea & $0.1 \%$ & 90 & 94 & 26 & 73 & 88 \\
\hline $\mathrm{NH}_{4} \mathrm{H}_{2} \mathrm{PO}_{4}$ & $0.2 \%$ & 88 & 94 & 29 & 70 & 90 \\
\hline $\mathrm{K}_{2} \mathrm{SO}_{4}$ & $0.2 \%$ & 88 & 94 & 38 & 68 & 79 \\
\hline $\mathrm{Ca}\left(\mathrm{NO}_{3}\right)_{2}$ & $0.2 \%$ & 88 & 92 & 43 & 77 & 94 \\
\hline $\mathrm{KNO}_{3}$ & $0.2 \%$ & 90 & 90 & 51 & 76 & 85 \\
\hline Hoagl. & $0.24 \%$ & 82 & 84 & 62 & 81 & 92 \\
\hline
\end{tabular}

*) sirkkataimi maan pinnalla, sirkkalehdet eivät täysin auenneet

*) the cotyledons not fully opened 
Taulukko 2. Ravinneliuosten vaikutus sirkkataimen kokoon 5 vrk:n kuluttua kylvöstä. Lämpötila 23 $25^{\circ} \mathrm{C}$, lisävalo $780 \mathrm{~lx}$.

Table 2. The effect of nutrient solutions on size of cucumber seedling after 5 days from sowing. Temperature $23-25^{\circ} \mathrm{C}$, additional light $780 \mathrm{~lx}$.

\begin{tabular}{|c|c|c|c|c|c|}
\hline $\begin{array}{l}\text { Käsittely } \\
\text { Treatment }\end{array}$ & & $\begin{array}{c}\text { Tuorepaino } \\
\text { Fresh weight } \\
\text { mg }\end{array}$ & $\begin{array}{l}\text { Kuivapaino } \\
\text { Dry weight } \\
\quad \mathrm{mg}\end{array}$ & $\begin{array}{c}\text { Sirkkalehdet } \\
\text { Cotyledons } \\
\mathrm{cm}^{2}\end{array}$ & $\begin{array}{c}\text { Sirkkavarsi } \\
\text { Hypocotyl } \\
\text { cm }\end{array}$ \\
\hline $\mathrm{H}_{2} \mathrm{O}$ & & 197 & 9.6 & 1.2 & 6.1 \\
\hline $\mathrm{NH}_{4} \mathrm{H}_{2} \mathrm{PO}_{4}$ & $0.2 \%$ & 186 & 10.3 & 1.3 & 5.2 \\
\hline urea & $0.1 \%$ & 200 & 10.6 & 1.4 & 5.6 \\
\hline $\mathrm{NH}_{4} \mathrm{NO}_{3}$ & $0.1 \%$ & 227 & 10.5 & 1.7 & 5.6 \\
\hline $\mathrm{K}_{2} \mathrm{SO}_{4}$ & $0.2 \%$ & 247 & 11.7 & 1.9 & 6.6 \\
\hline $\mathrm{Ca}\left(\mathrm{NO}_{3}\right)_{2}$ & $0.2 \%$ & 249 & 11.5 & 1.8 & 6.3 \\
\hline $\mathrm{KNO}_{3}$ & $0.2 \%$ & 301 & 12.2 & 2.2 & 7.2 \\
\hline \multirow[t]{3}{*}{ Hoagl. } & $0.24 \%$ & 330 & 12.3 & 2.5 & 7.3 \\
\hline & F & $23.67 * * *$ & $10.10^{* * *}$ & $20.67 * * *$ & $6.4^{* *}$ \\
\hline & $\mathrm{PME}_{5} \%$ & $31 \mathrm{mg}$ & $0.29 \mathrm{mg}$ & $0.31 \mathrm{~cm}^{2}$ & $0.28 \mathrm{~cm}$ \\
\hline
\end{tabular}

Taulukko 3. Täysravinne- ja $\mathrm{KNO}_{3}$-liuoksen vaikutus kurkun ja tomaatin taimettumiseen. Tulokset suhdelukuja; päivittäin todettu vedellä kastellulla alustalla taimettuneiden määrä $=100$. Lämpötila $20-25^{\circ} \mathrm{C}$.

Table 3. The effect of $\mathrm{KNO}_{\mathrm{3}}$ - and Hoagland-solutions on relative seedling emergence of cucumber and tomato. The daily number of seedlings at $\mathrm{H}_{2} \mathrm{O}$ - treatment $=100$. Temperature $20-25^{\circ} \mathrm{C}$.

\begin{tabular}{|c|c|c|c|c|c|c|c|c|}
\hline $\begin{array}{l}\text { Koekasvi } \\
\text { Plant }\end{array}$ & $\begin{array}{l}\text { Käsittely } \\
\text { Treatmen }\end{array}$ & & $\begin{array}{l}4 \text { vrk } \\
4 \text { days }\end{array}$ & $\begin{array}{l}5 \text { vrk } \\
5 \text { days }\end{array}$ & $\begin{array}{l}6 \text { vrk } \\
6 \text { days }\end{array}$ & $\begin{array}{l}7 \text { vrk } \\
7 \text { days }\end{array}$ & $\begin{array}{l}8 \text { vrk } \\
8 \text { days }\end{array}$ & $\begin{array}{l}9 \mathrm{vkr} \\
9 \text { days }\end{array}$ \\
\hline Kurkku (6 koetta) & $\mathrm{H}_{2} \mathrm{O}$ & & 100 & 100 & 100 & 100 & 一 & - \\
\hline Cucumber & $\mathrm{KNO}_{3}$ & $0.2 \%$ & 200 & 111 & 92 & 106 & - & 一 \\
\hline (6 experiments) & Hoagl. & $0.24 \%$ & 222 & 114 & 104 & 112 & 一 & - \\
\hline Tomaatti & $\mathrm{H}_{2} \mathrm{O}$ & & 一 & 100 & 100 & 100 & 100 & 100 \\
\hline (3 koetta) & $\mathrm{KNO}_{3}$ & $0.2 \%$ & - & 116 & 123 & 100 & 95 & 109 \\
\hline Tomato & Hoagl. & $0.24 \%$ & 一 & 142 & 159 & 117 & 110 & 116 \\
\hline (3 experiments) & & & & & & & & \\
\hline
\end{tabular}

Tomaatilla suoritetuissa kokeissa todettiin, että $\mathrm{KNO}_{3}$ - ja Hoagland-liuokset nopeuttivat taimettumista lämpötilan ollessa $20-25^{\circ} \mathrm{C}$ (taulukko 3 ) ja että käsittelyt lisäsivät sirkkataimien kokoa (taulukko 5). Kasvatuskaapeissa kurkulla suoritetuissa kokeissa todettiin edelleen, että käsittelyistä johtuva ero taimettumisnopeudessa pieneni lämpötilan noustessa $20^{\circ}$ :sta $30^{\circ}$ :een sirkkataimien koossa ilmenevien erojen kuitenkin säilyessä (kuva 1). 
TAIMETTUMinen SEeding EMERGENCE

$100 \%$
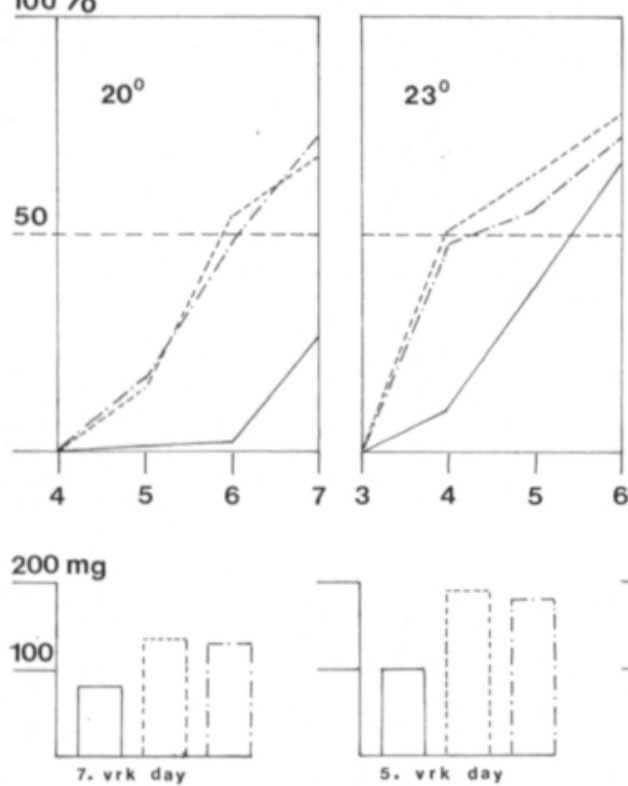

SIRKKATAIMEN TUOREPAINO

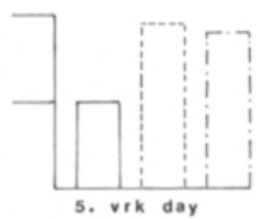

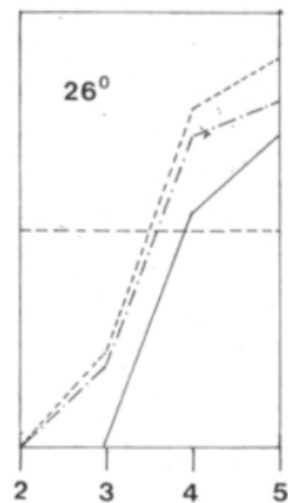
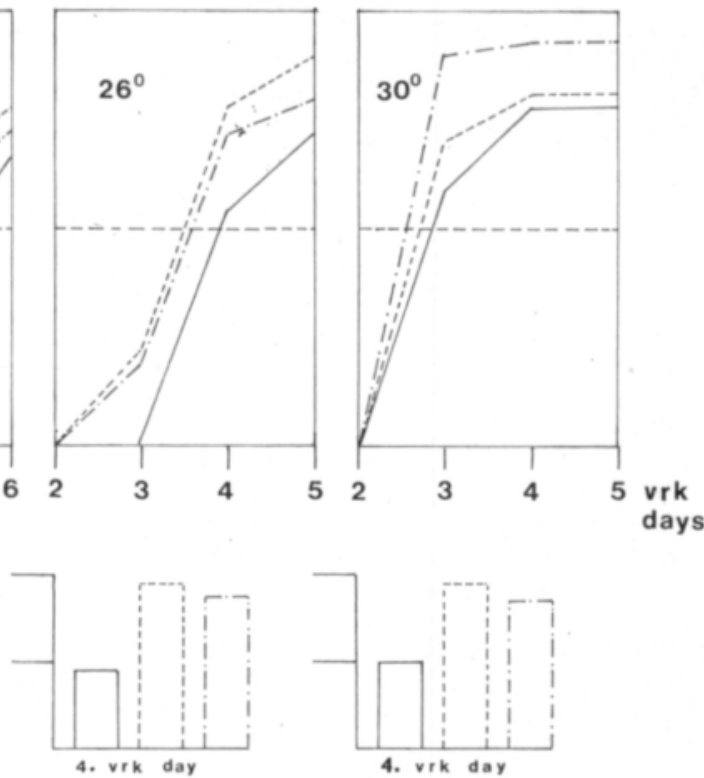

FRESH WEIGHT OF SEEDLING

Kuva 1. Lämpötilan ja ravinneliuoksen vaikutus kurkun taimettumiseen ja sirkkataimen painoon. Valoisuus $12000 \mathrm{~lx}, 14 \mathrm{t} / \mathrm{vrk}$.

Figure 1. Effect of temperature and nutrient solution treatment on seedling emergence and seedling weight of cucumber. Illumination of 12000 lx, 14 hours per day.

$-----=0.2 \% \mathrm{KNO}_{3}$

$-\cdot-\cdot-\cdot=0.24 \%$ Hoagland-liuos, Hoagland-solution

Taulukko 4. Ravinneliuoksen väkevyyden vaikutus kurkun sirkkataimen kokoon 6 vrk:n ja suhteelliseen taimettumiseen 4 vrk:n kuluttua kylvöstä. Lämpötila $21-23^{\circ} \mathrm{C}$, lisävalo $780 \mathrm{~lx}$.

Table 4. The effect of concentration of solution on seedling size of cucumber after 6 days and on relative seedling emergence after 4 days from sowing. Temperature $21-23^{\circ} \mathrm{C}$, additional light $780 \mathrm{~lx}$.

\begin{tabular}{|c|c|c|c|c|c|}
\hline \multicolumn{2}{|l|}{$\begin{array}{l}\text { Käsittely } \\
\text { Treatment }\end{array}$} & $\begin{array}{l}\text { Tuorepaino } \\
\text { Fresh weight } \\
\quad \text { mg }\end{array}$ & $\begin{array}{l}\text { Kuivapaino } \\
\text { Dry weight } \\
\text { mg }\end{array}$ & $\begin{array}{c}\text { Sirkkalehdet } \\
\text { Cotyledons } \\
\mathrm{cm}^{2}\end{array}$ & $\begin{array}{c}\text { Taimettuminen } \\
\text { Relative emergence } \\
4 \text { vrk, sl. } \\
4 \text { days }\end{array}$ \\
\hline $\mathrm{H}_{2} \mathrm{O}$ & & 158 & 10.3 & 1.6 & 100 \\
\hline KNO & $0.1 \%$ & 277 & 12.5 & 2.7 & 137 \\
\hline ", & $0.2 \%$ & 324 & 14.2 & 3.2 & 137 \\
\hline , & $0.3 \%$ & 317 & 14.1 & 3.0 & 143 \\
\hline Hoagl. & $0.12 \%$ & 244 & 11.6 & 2.7 & 151 \\
\hline , & $0.24 \%$ & 300 & 12.4 & 3.4 & 194 \\
\hline ", & $0.36 \%$ & 309 & 12.4 & 3.5 & 146 \\
\hline , & $0.48 \%$ & 273 & 12.8 & 3.5 & 157 \\
\hline & F & $25.89 * * *$ & $6.16^{* *}$ & $29.09 * * *$ & \\
\hline
\end{tabular}


Taulukko 5. Ravinneliuoksen väkevyyden vaikutus tomaatin sirkkataimen kokoon 9 vrk:n kuluttua kylvöstä. Lämpötila $20-22^{\circ} \mathrm{C}$, lisävalo $2500-3000 \mathrm{~lx}$.

Table 5. The effect of concentration of solution on seedling size of tomato after 9 days from sowing. Temperature $20^{\circ}-$ $22^{\circ} \mathrm{C}$, additional light $2500-3000 \mathrm{~lx}$.

\begin{tabular}{|c|c|c|c|c|c|}
\hline \multicolumn{2}{|l|}{$\begin{array}{l}\text { Käsittely } \\
\text { Treatment }\end{array}$} & $\begin{array}{c}\text { Tuorepaino } \\
\text { Fresh weight } \\
\text { mg }\end{array}$ & $\begin{array}{c}\text { Kuivapaino } \\
\text { Dry weight } \\
\text { mg }\end{array}$ & $\begin{array}{c}\text { Sirkkalehdet } \\
\text { Cotyledons } \\
\mathrm{cm}^{2}\end{array}$ & $\begin{array}{c}\text { Sirkkavarsi } \\
\text { Hypocotyl } \\
\mathrm{cm}\end{array}$ \\
\hline $\mathrm{H}_{2} \mathrm{O}$ & & 15 & 1.2 & 0.3 & 1.2 \\
\hline $\mathrm{KNO}_{3}$ & $0.1 \%$ & 29 & 2.2 & 1.0 & 1.6 \\
\hline$"$ & $0.2 \%$ & 26 & 2.3 & 0.8 & 1.5 \\
\hline , & $0.3 \%$ & 29 & 2.4 & 0.9 & 1.5 \\
\hline Hoagl. & $0.12 \%$ & 29 & 2.0 & 1.0 & 1.6 \\
\hline$"$ & $0.24 \%$ & 28 & 1.9 & 0.9 & 1.6 \\
\hline " & $0.36 \%$ & 30 & 2.2 & 1.0 & 1.7 \\
\hline & $\begin{array}{l}\text { F } \\
\text { PME }_{5 \%} \%\end{array}$ & $\begin{array}{l}5.48^{* *} \\
6.7 \mathrm{mg}\end{array}$ & & & \\
\hline
\end{tabular}

Taulukko 6. Typpeä $0.26 \mathrm{~g} / 1$ sisältävien ravinneliuosten vaikutus kurkun sirkkataimen kokoon 5 vrk:n ja suhteelliseen taimettumiseen 4 vrk:n kuluttua kylvöstä. Lämpötila $21-24^{\circ} \mathrm{C}$, lisävalo $2500-3000 \mathrm{~lx}$. Table 6. The effect of nutrient solutions containing $0.26 \mathrm{~g}$ nitrogen/l on seedling size of cucumber after 5 days and on relative seedling emergence after 4 days from sowing. Temperature $21-24^{\circ} \mathrm{C}$, additional light $2500-3000 \mathrm{~lx}$.

\begin{tabular}{|c|c|c|c|c|c|}
\hline $\begin{array}{l}\text { Käsittely } \\
\text { Treatment }\end{array}$ & $\begin{array}{l}\text { Tuorepaino } \\
\text { Fresh weight } \\
\text { mg }\end{array}$ & $\begin{array}{l}\text { Kuivapaino } \\
\text { Dry weight } \\
\text { mg }\end{array}$ & $\begin{array}{c}\text { Sirkkalehdet } \\
\text { Cotyledons } \\
\mathrm{cm}^{2}\end{array}$ & $\begin{array}{c}\text { Sirkkavarsi } \\
\text { Hypocotyl } \\
\mathrm{cm}\end{array}$ & $\begin{array}{l}\text { Taimettuminen } \\
\text { Relative emergence } \\
4 \text { vrk, sl. } 4 \text { days }\end{array}$ \\
\hline $\mathrm{H}_{2} \mathrm{O}$ & 114 & 12.6 & 1.8 & 1.5 & 100 \\
\hline urea & 116 & 12.2 & 1.7 & 1.4 & 100 \\
\hline $\mathrm{NH}_{4} \mathrm{H}_{2} \mathrm{PO}_{4}$ & 117 & 11.1 & 1.5 & 1.7 & 150 \\
\hline $\mathrm{Ca}\left(\mathrm{NO}_{3}\right)_{2}$ & 143 & 13.1 & 2.3 & 1.5 & 183 \\
\hline $\mathrm{NH}_{4} \mathrm{NO}_{3}$ & 149 & 13.3 & 2.4 & 1.5 & 217 \\
\hline $\mathrm{KNO}_{3}$ & 177 & 14.1 & 3.1 & 1.7 & 325 \\
\hline Hoagl. & 170 & 14.5 & 2.9 & 1.7 & 225 \\
\hline $\mathrm{F}$ & $16.32 * * *$ & $10.43 * * *$ & $26.60 * * *$ & 1.61 & \\
\hline $\mathrm{Pl}$ & $35 \mathrm{mg}$ & $1.1 \mathrm{mg}$ & $0.4 \mathrm{~cm}^{2}$ & - & \\
\hline
\end{tabular}

Ravinneliuoksen väkevyyden merkitystä selvitettiin käyttäen $\mathrm{KNO}_{3}-(0.1-0.3 \%)$ sekä Hoagland-liuosta $(0.12-0.48 \%)$. Tulokset näistä kokeista esitetään taulukoissa 4 ja 5 , joista ilmenee, että tutkituissa väkevyyksissä kurkku reagoi liuoskonsentraation muutokseen, mutta tomaatti ei. Niinpä kurkun taimettumisalustan kastelu $0.2 \% \quad \mathrm{KNO}_{3}: 11 \mathrm{a}$ antoi suurimman tuorepainon, lehtipinta-alan ja kuivapainon muihin käsittelyväkevyyksiin verraten. Tomaatilla ei vastaavia eroja syntynyt. 
Taulukko 7. Typpeä $0.26 \mathrm{~g} / 1$ ja kaliumia $0.77 \mathrm{~g} / 1$ sisältävien ravinneliuosten vaikutus kurkun sirkkataimen kokoon 5 vrk:n ja suhteelliseen taimettumiseen 4 vrk:n kuluttua kylvöstä. Lämpötila $23-25^{\circ} \mathrm{C}$, lisävalo $2500-3000 \mathrm{~lx}$.

Table 7. The effect of nutrient solutions containing $0.26 \mathrm{~g}$ nitrogen and $0.77 \mathrm{~g}$ potassium per litre on seedling size of cucumber after 5 days and on relative seedling emergence after 4 days from sowing. Temperature $23-25^{\circ} \mathrm{C}$, additional light 2500-3000 lx.

\begin{tabular}{|c|c|c|c|c|c|}
\hline $\begin{array}{l}\text { Käsittely } \\
\text { Treatment }\end{array}$ & $\begin{array}{c}\text { Tuorepaino } \\
\text { Fresh weight } \\
\text { mg }\end{array}$ & $\begin{array}{l}\text { Kuivapaino } \\
\text { Dry weight } \\
\text { mg }\end{array}$ & $\begin{array}{c}\text { Sirkkalehdet } \\
\text { Cotyledons } \\
\mathrm{cm}^{2}\end{array}$ & $\begin{array}{c}\text { Sirkkavarsi } \\
\text { Hypocotyl } \\
\mathrm{cm}\end{array}$ & $\begin{array}{l}\text { Taimettuminen } \\
\text { Relative emergence } \\
4 \text { vrk, sl. } 4 \text { days }\end{array}$ \\
\hline $\mathrm{H}_{2} \mathrm{O}$ & 122 & 13.9 & 1.4 & 2.2 & 100 \\
\hline urea $+\mathrm{K}_{2} \mathrm{SO}_{4}$ & 159 & 16.7 & 2.6 & 2.5 & 105 \\
\hline $\mathrm{NH}_{4} \mathrm{H}_{2} \mathrm{PO}_{4}+\mathrm{K}_{2} \mathrm{SO}_{4}$ & 170 & 16.8 & 2.5 & 2.4 & 158 \\
\hline $\mathrm{NH}_{4} \mathrm{NO}_{3}+\mathrm{K}_{2} \mathrm{SO}_{4}$ & 202 & 17.1 & 2.9 & 2.9 & 168 \\
\hline $\mathrm{KNO}_{3}$ & 231 & 18.2 & 3.1 & 3.1 & 200 \\
\hline F & $13.35 * * *$ & $9.2 * *$ & & & \\
\hline $\mathrm{PME}_{5} \%$ & $35 \mathrm{mg}$ & $1.8 \mathrm{mg}$ & & & \\
\hline
\end{tabular}

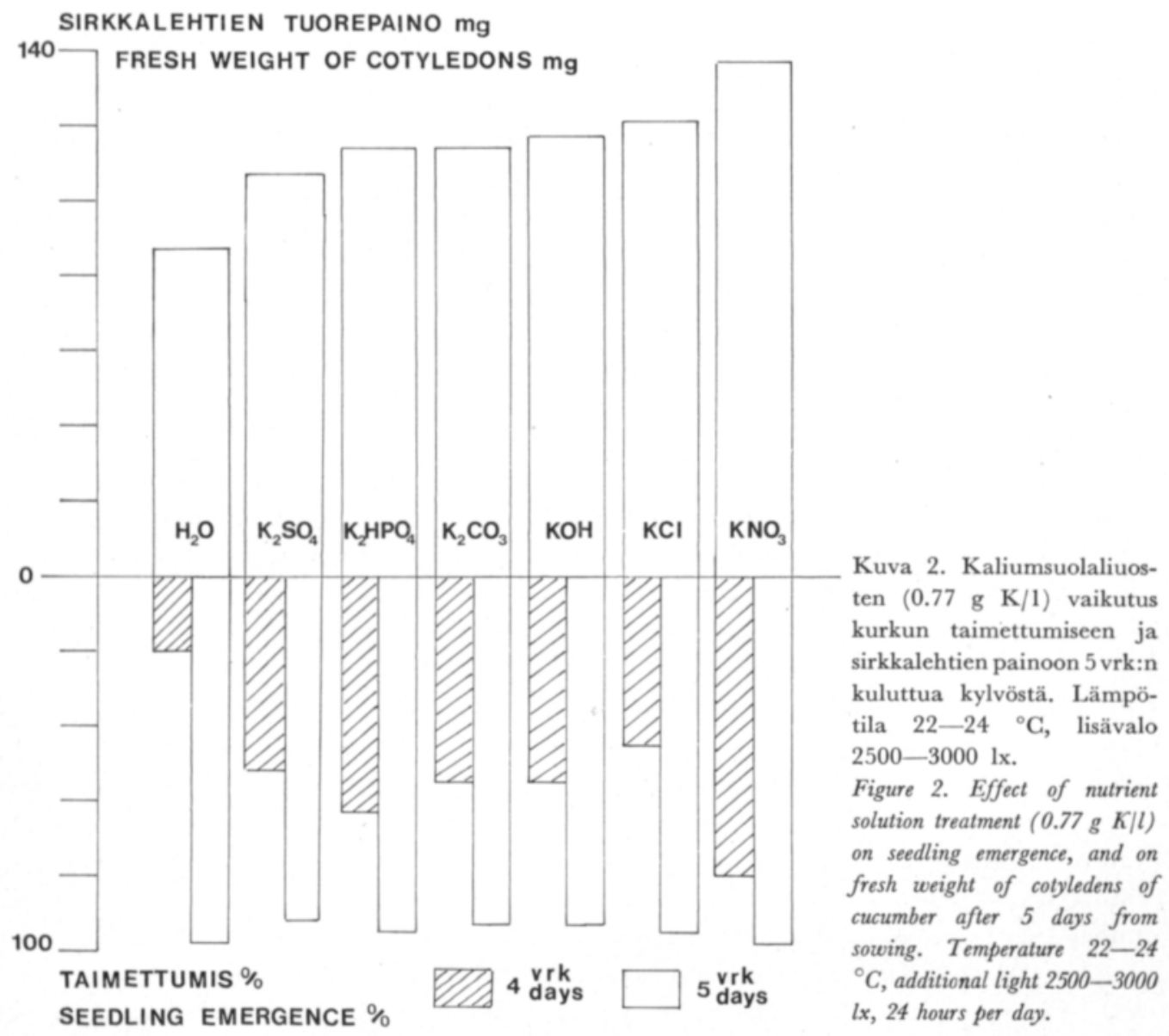


Kokeet typen ja kaliumin merkityksen selvittämiseksi. Koska useissa kokeissa ilmeni, että kaliumnitraatilla oli huomattava vaikutus koekasvien sirkkataimien kehittymiseen, järjestettiin kokeita typen ja kaliumin vaikutuksen selvittämiseksi. Koekasvina oli kurkku. Aluksi taimettumisalusta kasteltiin erilaisilla ravinneliuoksilla, jotka sisälsivät typpeä $0.26 \mathrm{~g} / \mathrm{l}$ (taulukko 6). Tulosten mukaan urea- ja $\mathrm{NH}_{4} \mathrm{H}_{2} \mathrm{PO}_{4}$-käsittelyt haittasivat sirkkataimien kehittymistä muiden käsittelyjen selvästi lisätessä sirkkataimien kokoa vedellä kasteltuihin verraten. Taimettuminen urea-käsittelyä lukuunottamatta nopeutui ravinneliuosten lisäyksen johdosta.

Seuraavissa kokeissa taimettumisalusta kasteltiin tislatulla vedellä taikka ravinneliuoksilla, jotka sisälsivät typpeä $0.26 \mathrm{~g} / \mathrm{l}$ ja kaliumia $\left(\mathrm{K}_{2} \mathrm{SO}_{4}:\right.$ na) $0.77 \mathrm{~g} / \mathrm{l}$ (taulukko 7 ). Tällöin kaliumsuolan lisäyksen jälkeen myös ne käsittelyt, joissa typpi oli urean tai monoammoniumfosfaatin muodossa, suurensivat sirkkataimien kokoa, eivät kuitenkaan yhtä paljon kuin käsittelyt ammonium- tai kaliumnitraattia sisältävillä liuoksilla.

Kaliumia seuraavan anionin merkitystä selvitettiin kastelemalla taimettumisalusta erilaisilla kaliumsuolaliuoksilla, jotka sisälsivät kaliumia $0.77 \mathrm{~g} / \mathrm{l}$. Tuloksista ilmenee (kuva 2), että kaikki tutkitut liuokset nopeuttivat taimettumista vedellä kasteltuihin verraten. Taimettumista nopeutti eniten $\mathrm{KNO}_{3}$-liuos, jonka vaikutuksesta sirkkataimet kehittyivät kookkaimmiksi. Kaliumsulfaattiliuoksella oli vähiten vaikutusta kurkun sirkkataimen kokoon.

Taimettumisalustan käsittelyn jälkivaikutusta tutkittiin käyttäen kastelussa Hoagland-, $\mathrm{KNO}_{3}$-liuosta tai tislattua vettä. Näiden kokeiden tuloksista todetaan (taulukko 8), että annettaessa kurkun tai tomaatin taimettumisalustaan $\mathrm{KNO}_{3}$ - tai Hoagland-liuosta taimet jatkokasvatuksessa kehittyvät suuremmiksi kuin taimettumisen tapahtuessa vedellä kastellussa alustassa. Ne taimet, jotka taimetettiin Hoagland-liuoksella kastellussa alustassa, kehittyivät neliviikkoisen jatkokasvatuksen aikana suuremmiksi kuin ne, joiden taimettumisalusta kasteltiin kaliumnitraattiliuoksella.

\section{Tulosten tarkastelu}

Ravinneliuoksen vaikutus taimettumisnopeuteen. Petrinmaljoissa suoritetuissa idätyskokeissa ei mikään $0.1-0.2 \%$ ravinneliuoksista selvästi nopeuttanut kurkun itämistä, mutta näistä usealla oli hiekka-alustalla taimettumista nopeuttava vaikutus vedellä kasteltuihin verraten. Ero taimettumisnopeudessa oli selvimmin nähtävissä sen vuorokauden kuluessa, jolloin sirkkataimet alkoivat työntyä esiin, ja tutkituista liuoksista taimettumista jouduttivat eniten täysravinneliuos ja $\mathrm{KNO}_{3}$-liuos. Todettiin myös, että lämpötilan lähetessä itämisnopeuden optimilämpötilaa käsittelyistä johtuvat erot taimettumisnopeudessa pienenivät. Saman suuntaiseen tulokseen päätyvät Ells (1963) sekä OYer ja KoEHLER (1966) käsiteltyään tomaatin siemeniä K-suolaliuoksilla; alhaisissa lämpötiloissa käsittelyt nopeuttivat taimettumista. Taimettumista jouduttavan vaikutuksen he olettavat perustuvan siemenen parantuneeseen hapensaantiin. Selitys taimettumisnopeuden eroihin saattaa myös perustua eri ravinteiden vaikutuksiin kehittyvän sirkkataimen aineenvaihdunnassa ja/tai suolojen osmoottisiin vaikutuksiin.

Ravinneliuoksen vaikutus sirkkataimen kokoon. Määritykset sirkkataimista tehtiin yleensä $1-2$ vrk:n kuluttua ensimmäisten taimien ilmaantumisesta. Taimettumisvaiheessa ei 
Taulukko 8. Taimettumisalustan käsittelyn vaikutus kurkun ja tomaatin tuorepainoon jatkokasvatuksen eri vaiheissa.

Table 8. The after-effects of nutrient solution treatments on fresh weight of cucumber and tomato 7-30 days after pricking out on peat sheets.

\begin{tabular}{|c|c|c|c|c|}
\hline $\begin{array}{l}\text { Koe } \\
\text { Experiment }\end{array}$ & $\begin{array}{l}\text { Taimettumisalustan } \\
\text { käsittely } \\
\text { Treatment } \\
\text { during emergence }\end{array}$ & \multicolumn{3}{|c|}{$\begin{array}{l}\text { Tuorepaino } \mathrm{g} \text {, vrk koulinnasta } \\
\text { Fresh weight } \mathrm{g} \text {, days from pricking }\end{array}$} \\
\hline $\begin{array}{l}\text { Kurkku, } \\
\text { Cucumber, }\end{array}$ & & $\begin{array}{l}14 \text { vrk } \\
14 \text { days }\end{array}$ & $\begin{array}{l}20 \text { vrk } \\
20 \text { days }\end{array}$ & $\begin{array}{l}27 \text { vrk } \\
27 \text { days }\end{array}$ \\
\hline $\begin{array}{l}\text { kylvö } 4.7 \cdot-69 \\
\text { koulinta } 9.7 .-69 \\
\text { sowing } 4.7 .-69 \\
\text { pricking } 9.7 .-69\end{array}$ & $\begin{array}{lll}\mathrm{H}_{2} \mathrm{O} & & \\
\mathrm{KNO}_{3} & 0.2 \% \\
\text { Hoagl. } & 0.24 \%\end{array}$ & $\begin{array}{l}0.81 \\
0.94 \\
1.06\end{array}$ & $\begin{array}{l}2.57 \\
3.37 \\
3.49\end{array}$ & $\begin{array}{l}6.79 \\
8.30 \\
9.26\end{array}$ \\
\hline $\begin{array}{l}\text { Kurkku, } \\
\text { Cucumber, }\end{array}$ & & $\begin{array}{l}7 \text { vrk } \\
7 \text { days } \\
\end{array}$ & $\begin{array}{l}14 \text { vrk } \\
14 \text { days }\end{array}$ & $\begin{array}{l}21 \text { vrk } \\
21 \text { days }\end{array}$ \\
\hline $\begin{array}{l}\text { kylvö } 19 \cdot 5 \cdot-71 \\
\text { koulinta } 24 \cdot 5 \cdot-71 \\
\text { sowing } 19.5 \cdot-71 \\
\text { pricking } 24 \cdot 5 \cdot-71\end{array}$ & $\begin{array}{ll}\mathrm{H}_{2} \mathrm{O} & \\
\mathrm{KNO}_{3} & 0.1 \% \\
, & 0.2 \% \\
, & 0.3 \%\end{array}$ & $\begin{array}{l}0.61 \\
0.63 \\
0.67 \\
0.66\end{array}$ & $\begin{array}{l}2.60 \\
3.18 \\
3.51 \\
3.10\end{array}$ & $\begin{array}{l}6.69 \\
9.14 \\
8.62 \\
8.64\end{array}$ \\
\hline $\begin{array}{l}\text { Tomaatti "Potentat", } \\
\text { Tomato "Potentat", }\end{array}$ & & $\begin{array}{l}14 \text { vrk } \\
14 \text { days }\end{array}$ & $\begin{array}{l}20 \text { vrk } \\
20 \text { days }\end{array}$ & $\begin{array}{l}27 \text { vrk } \\
27 \text { days }\end{array}$ \\
\hline $\begin{array}{l}\text { kylvö } 4.2 .-70 \\
\text { koulinta } 13 \cdot 2 .-70 \\
\text { sowing } 4.2 .-70 \\
\text { pricking } 13.2 .-70\end{array}$ & $\begin{array}{lll}\mathrm{H}_{2} \mathrm{O} & & \\
\mathrm{KNO}_{3} & 0.2 \% \\
\text { Hoagl. } & 0.24 \%\end{array}$ & $\begin{array}{l}0.19 \\
0.29 \\
0.29\end{array}$ & $\begin{array}{l}0.75 \\
1.18 \\
1.17\end{array}$ & $\begin{array}{l}2.66 \\
3.92 \\
4.08\end{array}$ \\
\hline $\begin{array}{l}\text { Tomaatti "Revermun", } \\
\text { Tomato "Revermun", }\end{array}$ & & $\begin{array}{l}10 \text { vrk } \\
10 \text { days }\end{array}$ & $\begin{array}{l}20 \text { vrk } \\
20 \text { days }\end{array}$ & $\begin{array}{l}30 \text { vrk } \\
30 \text { days }\end{array}$ \\
\hline $\begin{array}{l}\text { kylvö } 3.2 .-71 \\
\text { koulinta } 12.2 .-71 \\
\text { sowing } 3.2 .-71 \\
\text { pricking } 12.2 .-71\end{array}$ & $\begin{array}{lll}\mathrm{H}_{2} \mathrm{O} & & \\
\mathrm{KNO}_{3} & 0.2 \% \\
\text { Hoagl. } & 0.24 \%\end{array}$ & $\begin{array}{l}0.09 \\
0.13 \\
0.14\end{array}$ & $\begin{array}{l}1.24 \\
1.55 \\
1.60\end{array}$ & $\begin{array}{r}9.68 \\
10.92 \\
11.70\end{array}$ \\
\hline
\end{tabular}

avautumassa olevien sirkkalehtien koossa voitu silmin havaita eroavuuksia, mutta jo muutaman tunnin kuluttua lehtien aukeamisesta eroja oli nähtävissä. Useiden erilaisten käsittelyjen johdosta kurkun ja tomaatin sirkkalehdet kasvoivat suuremmiksi kuin vedellä kastellulla alustalla. Käsittelyillä voitiin lisätä myös sirkkavarren pituutta ja kuivaaineen määrää.

Tulosten mukaan koekasvit siis voivat käyttää hyödykseen saatavilla olevia ravinteita heti sirkkalehtien avauduttua ja mahdollisesti jo aikaisemmin. Liuoksissa annetuista ravinteista erityisesti kaliumin vaikutus oli voimakas. Onkin todettu, että kalium voi lisätä 
lehtivihreän muodostumista kurkun sirkkalehdissä (KNYPL 1969, 1970) ja täten nopeuttaa sirkkataimen kasvua (BARKER et al. 1970). Käsillä olevassa tutkimuksessa todettiin edelleen, että kaliumin määrän ollessa eri ravinneliuoksissa saman suuruinen $\mathrm{KNO}_{3}$ käsittely johti suurimpaan eroavuuteen vedellä kasteltuihin nähden. Tämä selittynee osittain $\mathrm{NO}_{3}$-ionin synergistisestä vaikutuksesta ja osittain typpivaikutuksesta.

Typen merkitystä selvittävissä kokeissa ravinneliuos, joka sisälsi typpeä $0.26 \mathrm{~g} / \mathrm{l} \mathrm{am-}$ moniumnitraattina, lisäsi kurkun sirkkataimen painoa. Sen sijaan saman verran typpeä sisältävillä urea- tai monoammoniumfosfaattiliuoksilla ei ollut taimien kasvua edistävää vaikutusta, kun taas kalsiumnitraattiliuoksen vaikutus oli samankaltainen kuin ammoniumnitraattiliuoksen. Nämä tulokset osoittavat, että typen vaikutus kurkun sirkkataimeen on $\mathrm{NO}_{3}$-muodossa kasvua lisäävä, mutta ammoniumin tai urean muodossa ei. Päinvastoin jo varsin laimeilla $(0.001 \mathrm{~N})$ ammoniumsuolaliuoksilla on todettu olevan haittavaikutuksia kurkun sirkkataimeen (BARKER et al. 1970).

Kaliumin ja typen lisäksi ei tässä tutkimuksessa muiden ravinteiden merkitystä erikseen selvitetty. Tulokset fosforia ja kalsiumia sisältäneistä käsittelyistä antavat kuitenkin aiheen olettaa, että siemenen vararavinnossa olevat kivennäisvarat ovat näiden ravinteiden suhteen sirkkataimen alkukehitykselle riittävät. Tämä olettamus usein yleistetään kaikkia ravinteita koskevaksi, mikä kuitenkaan ei kaliumin ja typen suhteen näytä perustellulta.

Vaikka tutkimuksessa pitäydyttiin verraten laimeitten liuosten käyttöön, todettiin, että koekasvit reagoinnissaan konsentraation muutokseen poikkeavat toisistaan. Taimettumisalustan lannoituskysymys tulisi siis selvittää kasvikohtaisesti.

Taimettumisvaiheessa annetun käsittelyn jälkivaikutus taimien myöhempään kasvuun oli suuri, vaikka sirkkataimet olivat erilaisissa olosuhteissa vain lyhyen aikaa. Tämä tukee käsitystä, että sirkkataimivaiheen olosuhteet saattavat huomattavasti määrätä kasvien myöhempää kehitystä ja että antamalla taimettumisvaiheessa sopivaa lannoitusta kasvien kehitystä voidaan jouduttaa.

\section{Tiivistelmä}

Tutkimuksessa selvitettiin erilaisten ravinneliuosten, liuosten konsentraation, typen ja kaliumin vaikutusta kurkun ja tomaatin taimettumisnopeuteen ja sirkkataimen kehittymiseen hiekka-alustalla. Samalla selvitettiin taimettumisalustan käsittelyn jälkivaikutusta.

Monet $0.1-0.3 \%$ ravinneliuoksista nopeuttivat kurkun taimettumista, niistä eniten täysravinne- ja $\mathrm{KNO}_{3}$-liuos. Taimettumisen nopeutuminen todettiin selvimpänä ensimmäisen taimettumisvuorokauden kuluessa. Erot taimettumisnopeudessa pienenivät lämpötilan ollessa lähellä itämisen optimilämpötilaa. Myös tomaatin taimettuminen nopeutui $\mathrm{KNO}_{3}$ - ja täysravinnekäsittelyjen johdosta.

Kurkun sirkkataimen koko oli suurin, kun annettu ravinneliuos sisälsi kaliumia ja typpeä nitraattimuodossa. Tutkituista ravinneliuoksista $0.24-0.36 \%$ Hoagland- ja $0.2 \% \mathrm{KNO}_{3}$-liuos lisäsivät eniten sirkkataimien kasvua kurkulla. Tomaatti ei reagoinut vastaavasti liuoskonsentraation muutokseen.

Taimettumisalustaan annettujen ravinteiden positiivinen jälkivaikutus koekasvien myöhempään kasvuun todettiin vielä 4 viikon kuluttua taimien siirrosta samanlaisiin kasvuoloihin. 


\section{KIRJALLISUUTTA}

Barker, A. V., Maynard, D. N., Mioduchowska, B. \& Buch, A. 1970. Ammonium and salt inhibition of some physiological processes associated with seed germination. Physiol. Plant. 23:898-907. Cochran, W. G. \& Cox, G. M. 1962. Experimental designs. 595 p. New York.

ELLs, J. E. 1963. The influence of treating tomato seed with nutrient solutions on emergence rate and seedling growth. Proc. Amer. Soc. Hort. Sci. 83:684-687.

Hartmann, H. T. \& Kester, D. E. 1968. Plant propagation. 702 p. New Jersey.

KNYPL, J. S. 1970. Complementary action of potassium and benzyl-aminopurine on growth, chlorophyll, protein and RNA synthesis in cucumber cotyledons. Curr. Sci. 39:534-535.

KNYPL, J. S. 1971. Control of protein and RNA synthesis by AMO-1618 and other growth retardants in cucumber cotyledons. Biochem. Physiol. Pflanzen 162:127-141.

Mayer, A. M. \& Poljakoff-Mayber, A. 1963. The germination of seeds. 236 p. Oxford.

OYer, E. B. \& Koenler, D. E. 1966. A method of treating tomato seed to hasten germination and emergence at suboptimal temperatures. Proc. 17. Int. Hort. Congr. 1, 626.

Sunonen, I. 1970. Tuloksia kylvöalustan ravinteisuudesta. Puutarha-Uutiset 22:400-401.

WENT, F. M. 1957. The experimental control of plant growth. 343 p. New York. 